\title{
School Culture and Instructional Leadership of High-Performing and Low-Performing Schools: Patterns of Variation and Relationship
}

\author{
H. Sufean \\ Department of Educational Management \& Policy, Faculty of Education, University of Malaya, Malaysia
}

\begin{abstract}
Abundant literature posits that leadership and culture are linked to each other in all organizations. In school organizations, instructional leadership has been asserted as the most crucial type of leadership that is closely linked to professional culture in schools. The main reason is that instructional leadership pertains to the core functions of education, instruction, and learning in classrooms, which also constitute the main elements of a school culture.

The purpose of the study presented in this paper was to examine and analyze the patterns of variation and relationship between instructional leadership and school culture of some high-and low-performing secondary schools. This study found that the school culture and instructional leadership of high-performing schools were markedly different from that of the low-performing schools. In high-performing schools, the school heads maintained positive attitudes toward students, staff, and parents, created a school culture and climate conductive to learning, and predominantly emphasized teachers' professional values and collegiality. Communicating the vision and mission to the staff and maintaining positive attitudes toward students, staff, and parents were the most striking aspects that differentiated the two school-types in terms of instructional leadership. As for culture, collaboration and school-wide planning were significantly linked to instructional leadership.

The important implication from this study was that the selection of school heads must take into account their human-oriented skills, and consequently, training sessions and seminars should be directed at human relation skills for the new and upcoming principals. Apart from that, to be a high-performing school, a school head should establish clear school vision and mission, set professional goals for staff, and build a two-way communication channel with teachers. School heads also should set high expectations on teachers and students, and create a positive school culture and climate of learning.
\end{abstract}

Keywords: instructional leadership, school culture, high-performance schools, characteristics of effective school leadership

\section{Background Of The Study}

Schools are educational institutions built by the society to educate children and youth with the relevant knowledge, skills, cultural traditions, and values in order to enable them to function well in the society and to continue building the society from generation to generation. That is the core function of schools in any society. Correspondingly, the curriculum and education process in schools have to change according from time to time in tandem with the progress of knowledge and life condition. Within the school compound, apart from ethos, the values and beliefs of school leaders, teachers, and children are covert forces that shape the school culture [Hofstede \& Hofstede (2005); Schein (2004); Sufean, (2002, 2009)]. This is the reason why every school has its own unique culture. However, among the numerous factors, it has been argued that it is the school leaders' attitude and aptitude which constitute the utmost important factor that strongly shapes a school culture. Henceforth, instructional leadership - among other types of school leadership - has been theorized to be closely linked to school culture and effectiveness (McEwan, 2002). To function as an effective instructional leader, a principal must be able to exhibit high professionalism and promote a healthy culture. The personal and professional qualities of a principal would be a strong advantage for assuming the role of an instructional leader. Saphier and King (1985) posit that the leader's role in school culture is to instill upon students and teachers an ever-present awareness of the cultural norms in their daily interactions, decisions, and plans, thus shaping the way events take place. Hallinger and Leithwood (1998) noted that culture and climate "compose of those facets of a school that shape the attitudes and behaviors of staff and students toward instruction and learning" (p.140). Culture is thought to be linked explicitly and implicitly to all the functions of a school organization.

Cavanagh and Dellar (1996) conceptualized that school culture as comprising eight domains, namely professional values, teachers as learners, collegiality, mutual empowerment, collaboration, shared vision, 
transformational leadership, and school-wide planning. Their conceptualization mostly focused on the roles and functions of teachers as well as their commitment in operating the affairs of schools, as if teachers were the main determinant in shaping school culture.

Many cultures, including school culture, go through a cycle of birth, change, destruction, and rebirth (Schein, 2004). During the birth process, people create the culture by sharing their assumptions to shape the group's identity. The culture then begins to shape the individuals with certain values and beliefs, and in time new members join and the culture changes with the group dynamics. Cheng (2000) and Schein (2004) argue that creating and managing culture is the most important thing leaders do. If the culture deviates from the desired pattern, leaders may need to destroy the existing culture and nurture the rebirth of the new culture (Deal \& Peterson, 1999). Schein also points out that the "ultimate act of leadership is to destroy culture when it is viewed as dysfunctional." (2004, p. 11).

Effective school leaders can gauge and shape a culture that fulfils the required expectations and values of the school and local community [Bennis and Nanus (1985), and Sergiovanni (2000)]. Foresight and insight are needed for understanding the rituals, symbols, and behaviors of individuals in the school. Also, examining the school history and ethos can assist a school leader to understand the past, present, and future realities and dreams. Subsequently, school leaders ought to share their dream, vision, beliefs, and values with teachers and students so that they are all directed toward some beneficial and purposeful ends. Deal and Peterson (1999) believe that deep and shared leadership creates the strongest and tightest cultures.

In 2002, McEwan proposed that there were seven steps to effective instructional leadership, based on her research and personal experience as an effective principal. The following are the seven steps proposed by McEwan:

- Establish clear instructional goals;

- Be there for your staff;

- Create a school culture and climate conducive to learning;

- Communicate the vision and mission of your school;

- Set high expectations;

- Develop teacher leaders; and

- Maintain positive attitudes toward students, staffs and parents.

According to Mitchell and Castle (2005), the concept of the principal as instructional leader emerged in the educational field during the 1970s as a factor for improving school effectiveness in the USA. But this concept was not novel to other countries that had all the while understood that a school head must be a very senior and experienced teacher who could lead professionally other junior teachers in school. The school head became the leader who shaped the school organization via the application of instructional leadership model. Hallinger (2003) identified instructional leadership model in the 1980s as "strong, directive leadership focused on curriculum and instruction from the principal" (p. 329). The top-down approach became apparent in leadership that "focuses predominantly on the role of the school principal in coordinating, controlling, supervising, and developing curriculum and instruction in the school" (Hallinger, 2003, p. 331).

Hallinger (2003) synthesized various essential characteristics of instructional leadership and noted that the principal's expertise and character both needed to be goal-oriented, and that there must be a focus on student outcomes and achievement. The principal also needed to help improve teaching and learning through curriculum and instruction. Hallinger pointed out principals who "shared leadership responsibility with others would be less subject to burnout than principal 'heroes' who attempt the challenges and complexities of leadership alone” (p. 345). Blasé and Blasé (1999), and Brewer (2001) outlined the focus of instructional leadership as concentrating on instruction; building a community of learners; sharing decision making; sustaining the basics, leverage time; supporting ongoing professional development for all staff; redirecting resources to support a multifaceted school plan and creating a climate of integrity, inquiry, and constant improvement.

As previously alluded to, instructional leadership is gaining more and more attention as it is linked to school accountability and school improvement policies in many countries. Hoy \& Miskel (2008) suggested that instructional leadership evolved from simple heroic conception to rather complex contingency models of leadership. Obviously, the roles of the principal become critical in exhibiting dispositions associated with instructional leadership for school improvement in this era of accountability.

\section{Purpose Of The Study}

The primary purpose of the study was to profile the salient patterns of differences between highperforming and low-performing schools in terms of school culture and instructional leadership. In addition, the secondary purpose of the study was to determine whether there was a strong link between instructional leadership and school culture with respect to the two school-types. 


\section{Research Methodology}

The study employed two sets of survey instrument, namely the Effective Instructional Leadership Questionnaire (EILQ) developed by McEwan (2002), and the School Culture Elements Questionnaire (SCEQ) developed by Cavanaugh and Dellar (1996).The EILQ consisted of seven domains or sub-constructs and the SECQ with eight domains mentioned before - refer to Tables 1 and 2 for the complete list of domains. Some necessary items were added to both questionnaires to suit the local context, but the addition did not tantamount to changes that would alter the construct and theoretical validity of both questionnaires because the original categorical domains or sub-construct were strictly maintained. The two sets of questionnaire had all items with a five-point ordinal scale, ranging from 1 (not present at all) to 3 (moderately present) to 5 (strongly present). Both questionnaires were translated to Malay and then pilot-tested with teachers in a secondary school. Doublereverse translation was used to check the survey questionnaires' linguistic compatibility and similarity, i.e. English to Malay and back to English.

For the actual study, we identified five high-performing public secondary schools and five lowperforming public secondary schools in the state of Selangor-the richest state in Malaysia with a lot of business corporations and industries. The basis of high performance was determined by the following criteria:

- School principals were awarded with the "excellent principal" title;

- Schools categorized as the high-performance schools by the state authority;

- A high percentage of students scored distinction grades in national examinations at the middle and high school levels; and

- Schools that received many awards and trophies in sports and co-curricular activities at the district and state levels.

On the other hand, low performance schools did not have any of those characteristics.

As for the sample of survey respondents, 15 teachers from each school were randomly selected from the teacher lists provided by the principals of the ten schools involved in the study. The respondents were given the two sets of questionnaires by ordinary mail, and they were instructed to maintain confidentiality and answer the questionnaires in a week. As many as 123 respondents returned back the questionnaires, but 14 of them did not fully answer and thus their questionnaires were discarded; hence, only questionnaire sets by 109 respondents were examined and analyzed, i.e. 54 from the high-performing schools and 55 from the low-performing schools.

\section{Data Analysis And Findings}

Data from the survey forms were coded and analyzed using the SPSS software (Statistical Package for the Social Sciences, Version 21). The main results of the analysis are portrayed in four main tables, as discussed in this section. Table 1 shows the mean scores and t-test values for the low-performing and highperforming schools.

Table 1: Differences of Means between High-performing (HP) and Low-performing (LP) Schools in terms of the Seven Domains of Instructional Leadership

\begin{tabular}{|c|c|c|c|c|}
\hline Instructional Leadership Domains & $\begin{array}{l}\text { LP } \\
\text { Mean }\end{array}$ & $\begin{array}{l}\text { HP } \\
\text { Mean }\end{array}$ & $\begin{array}{l}\text { t-test } \\
\text { value }\end{array}$ & $\begin{array}{l}\text { Sig. level } \\
\text { (2-talied) }\end{array}$ \\
\hline \multicolumn{5}{|l|}{ Domain One: } \\
\hline Establish clear instructional goals for teachers & 2.7451 & 3.6897 & 7.796 & 0.000 \\
\hline Support and assist teachers in doing their job & 2.3791 & 3.5690 & 9.111 & 0.000 \\
\hline \multicolumn{5}{|l|}{ Domain Three: } \\
\hline \multicolumn{5}{|l|}{ Domain Four: } \\
\hline Communicate the vision and mission to staff & 2.5752 & 3.9655 & 12.967 & 0.000 \\
\hline \multicolumn{5}{|l|}{ Domain Five: } \\
\hline Set high expectations for the staff & 2.1429 & 3.0394 & 7.937 & 0.000 \\
\hline \multicolumn{5}{|l|}{ Domain Six: } \\
\hline \multicolumn{5}{|l|}{ Domain Seven: } \\
\hline $\begin{array}{l}\text { Maintain positive attitudes toward students, staff, and } \\
\text { parents. }\end{array}$ & 2.9776 & 4.0690 & 10.052 & 0.000 \\
\hline
\end{tabular}


Results in Table 1 showed that the mean score values for the high-performing schools were consistently higher than those for the low-performing schools in all seven domains of instructional leadership. $\mathrm{T}$-test values revealed that the differences were significant for all the seven domains. The most striking difference between the two school-types was for Domain Four (t-test value of 12.967), i.e. instructional leadership which communicated school vision and mission. The other fairly striking differences were for Domains Seven and Three, i.e. instructional leaders who maintained positive attitudes towards students, staff, and parents, and leaders who created a school culture and climate conducive to learning respectively.

Next, Table 2 shows the differences of the mean score values and the t-test values for the high-performing and low-performing schools in terms of school culture.

Table 2: Differences of Means between High-performing and Low-performing schools in terms of the Eight Domains of School Culture

\begin{tabular}{|c|c|c|c|c|}
\hline School culture domains & $\begin{array}{l}\text { LP } \\
\text { Mean }\end{array}$ & $\begin{array}{l}\text { HP } \\
\text { Mean }\end{array}$ & $\begin{array}{l}\text { t-test } \\
\text { value }\end{array}$ & $\begin{array}{l}\text { Sig. } \\
\text { (2-talied) }\end{array}$ \\
\hline \multicolumn{5}{|l|}{ Domain One: } \\
\hline Professional values & 3.5515 & 4.0323 & 5.381 & $0.000 *$ \\
\hline \multicolumn{5}{|l|}{ Domain Two: } \\
\hline Teachers as learners & 3.7943 & 4.0194 & 3.360 & $0.001 *$ \\
\hline \multicolumn{5}{|l|}{ Domain Three: } \\
\hline Collegiality & 4.0907 & 4.2069 & 1.308 & 0.194 \\
\hline \multicolumn{5}{|l|}{ Domain Four: } \\
\hline Mutual empowerment & 3.4975 & 3.6789 & 2.235 & $0.028 *$ \\
\hline \multicolumn{5}{|l|}{ Domain Five: } \\
\hline Collaboration & 2.9510 & 3.8060 & 7.460 & $0.000 *$ \\
\hline \multicolumn{5}{|l|}{ Domain Six: } \\
\hline Shared visions & 3.3946 & 3.5517 & 1.946 & 0.054 \\
\hline \multicolumn{5}{|l|}{ Domain Seven: } \\
\hline School-wide planning & 3.2500 & 3.6056 & 3.232 & $0.002 *$ \\
\hline \multicolumn{5}{|l|}{ Domain Eight: } \\
\hline Transformational leadership & 3.1789 & 3.5474 & 5.168 & $0.000 *$ \\
\hline
\end{tabular}

Results in Table 2 showed that the mean score values for the high-performing schools were consistently higher than those for the low-performing schools in all eight domains of school culture. However, t-test values revealed that the differences were significant for six domains only, not for the other two domains, namely collegiality and school-wide planning. The most striking difference between the two school-types was for Domain Five, i.e. collaboration. The other fairly striking differences were for Domains One and Eight, i.e. school culture that emphasized professional values and transformational leadership respectively.

The results implied that both high- and low-performing schools were similar in terms of school culture that emphasized collegiality and school-wide planning. Teachers of both school-types upheld the same spirit of collegiality and similarly engaged in planning their school affairs.

How strong is the relationship between instructional leadership and school culture? Table 3 shows Spearman correlation coefficient values, which reflect the relationships between the domains of instructional leadership with that of school culture. Data for both school-types were aggregated together to examine the overall relationship between instructional leadership and school-culture.

Table 3: Correlations Among Domains of Instructional Leadership and School Culture

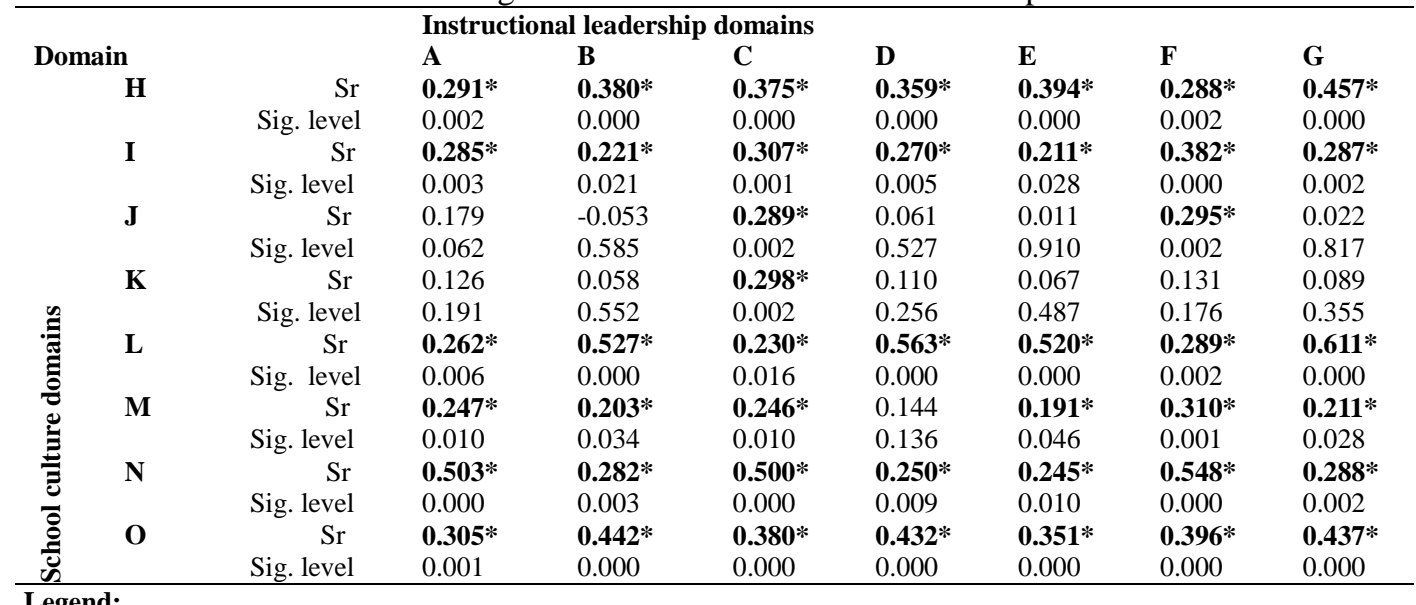

$\mathrm{Sr}$ is Spearman correlation coefficient. Strong or high correlation if $\mathrm{Sr}$ is more than 0.7500 ; moderate correlation if $\mathrm{Sr}$ is in the range 0.4500 to 0.7499 , and weak or low correlation if $\mathrm{Sr}$ is in the range of 0.1000 to 0.4499 . 
Sig. level: $*$ Correlation is significant at $\mathrm{p}=$ or $<0.05$ level $(2$-tailed $)$

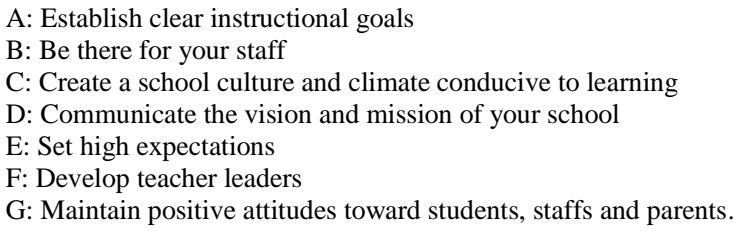

$\mathrm{H}$ : Professional values I: Teachers as learners J: Collegiality

$\mathrm{K}$ : Mutual empowerment

L: Collaboration

M: Shared visions

N: School-wide planning

O: Transformational leadership

Based on the results in Table 3, cumulatively, there were low to moderate correlations among the domains of school culture and instructional leadership. Generally, results showed that the seven domains of instructional leadership were significantly linked to six domains of school culture, but not (or less so) to the other two, namely collegiality and mutual empowerment.

What would the pattern be if the correlation analysis was done separately for each school-type? Table 4 shows Spearman correlation coefficient values portraying the relationship between instructional leadership and school culture in low-performing schools.

Table 4: Correlations Among Domains of Instructional Leadership And School Culture In Low-Performing

\begin{tabular}{|c|c|c|c|c|c|c|c|c|c|}
\hline \multicolumn{10}{|c|}{ Schools } \\
\hline \multicolumn{2}{|c|}{ Domain } & & $\mathbf{A}$ & B & C & D & $\mathbf{E}$ & $\mathbf{F}$ & G \\
\hline & \multirow[t]{2}{*}{$\mathbf{H}$} & $\mathrm{Sr}$ & -0.033 & 0.241 & -0.123 & -0.034 & 0.275 & -0.093 & $0.320 *$ \\
\hline & & Sig. level & 0.819 & 0.089 & 0.391 & 0.812 & 0.051 & 0.518 & 0.022 \\
\hline & \multirow[t]{2}{*}{$\mathbf{I}$} & & -0.171 & 0.066 & -0.050 & -0.027 & 0.060 & 0.153 & 0.148 \\
\hline & & Sig. level & 0.229 & 0.648 & 0.730 & 0.852 & 0.678 & 0.285 & 0.301 \\
\hline & \multirow[t]{2}{*}{$\mathbf{J}$} & & 0.095 & -0.270 & $0.371 *$ & -0.172 & -0.201 & 0.187 & -0.199 \\
\hline & & Sig. level & 0.507 & 0.055 & 0.007 & 0.228 & 0.156 & 0.190 & 0.160 \\
\hline & \multirow[t]{2}{*}{$\mathbf{K}$} & & -0.062 & -0.151 & 0.098 & -0.241 & -0.109 & -0.076 & -0.137 \\
\hline & & Sig. level & 0.663 & 0.290 & 0.492 & 0.089 & 0.447 & 0.598 & 0.337 \\
\hline \multirow{4}{*}{ 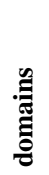 } & \multirow[t]{2}{*}{$\mathbf{L}$} & & -0.165 & $0.395^{*}$ & $-0.397 *$ & 0.229 & $0.409 *$ & -0.159 & $0.506^{*}$ \\
\hline & & Sig. level & 0.247 & 0.004 & 0.004 & 0.106 & 0.003 & 0.264 & 0.000 \\
\hline & \multirow[t]{2}{*}{$\mathbf{M}$} & & -0.077 & 0.101 & 0.255 & -0.088 & 0.162 & 0.108 & 0.170 \\
\hline & & Sig. level & 0.592 & 0.480 & 0.071 & 0.538 & 0.257 & 0.450 & 0.233 \\
\hline \multirow{2}{*}{ 总 } & \multirow[t]{2}{*}{$\mathbf{N}$} & $\mathrm{Sr}$ & 0.339* & -0.099 & $0.395 *$ & -0.091 & -0.034 & 0.250 & -0.017 \\
\hline & & Sig. level & 0.015 & 0.490 & 0.004 & 0.527 & 0.812 & 0.077 & 0.906 \\
\hline \multirow{2}{*}{$\overline{8}$} & \multirow[t]{2}{*}{$\mathbf{O}$} & $\mathrm{Sr}$ & 0.041 & $0.287 *$ & 0.037 & 0.095 & 0.190 & 0.019 & 0.240 \\
\hline & & Sig. level & 0.776 & 0.041 & 0.798 & 0.505 & 0.181 & 0.897 & 0.090 \\
\hline
\end{tabular}

Legend:

$\mathrm{Sr}$ is Spearman correlation coefficient.

Sig. level: * Correlation is significant at $\mathrm{p}=$ or $<0.05$ level $(2$-tailed $)$

A: Establish clear instructional goals

$B$ : Be there for your staff

C: Create a school culture and climate conducive to learning

D: Communicate the vision and mission of your school

E: Set high expectations

F: Develop teacher leaders

G: Maintain positive attitudes toward students, staffs and parents
$\mathrm{H}$ : Professional values
I: Teachers as learners
J: Collegiality
K: Mutual empowerment
L: Collaboration
M: Shared visions
N: School-wide planning
O: Transformational leadership

Based on the results in Table 4, in general there was a weak or slight relationship between instructional leadership and school culture in low-performing schools. Most of the domains in instructional leadership were not significantly correlated with the domains of school culture, except for a few domains such as mutual empowerment and school-wide planning of the school culture. For examples:

- Instructional leadership that established clear instructional goals was significantly correlated with the culture domain of school-wide planning.

- Instructional leadership that constantly supported the staff was significantly linked to the culture domain of collaboration. 
- Instructional leadership that set high expectations was significantly correlated with the culture domain of collaboration.

Table 5shows Spearman correlation coefficient values, which portray the relationships among the domains of instructional leadership with that of school culture in high-performing schools.

Table 5: Correlations Among Domains of Instructional Leadership and School Culture in High-Performing

\begin{tabular}{|c|c|c|c|c|c|c|c|c|c|}
\hline \multicolumn{10}{|c|}{ Schools } \\
\hline & & & \multicolumn{7}{|c|}{ Instructional leadership domains } \\
\hline \multicolumn{2}{|c|}{ Domain } & & A & B & C & D & $\mathbf{E}$ & $\mathbf{F}$ & G \\
\hline & \multirow[t]{2}{*}{$\mathbf{H}$} & $\mathrm{Sr}$ & 0.098 & -0.013 & $0.320 *$ & 0.043 & 0.039 & 0.149 & 0.119 \\
\hline & & Sig. level & 0.466 & 0.923 & 0.014 & 0.749 & 0.769 & 0.266 & 0.374 \\
\hline & \multirow[t]{2}{*}{$\mathbf{I}$} & $\mathrm{Sr}$ & $0.351 *$ & -0.018 & $0.296^{*}$ & 0.151 & 0.001 & $0.353 *$ & 0.069 \\
\hline & & Sig. level & 0.007 & 0.896 & 0.024 & 0.259 & 0.995 & 0.007 & 0.609 \\
\hline & \multirow[t]{2}{*}{$\mathbf{J}$} & $\mathrm{Sr}$ & 0.168 & -0.050 & 0.175 & 0.127 & 0.083 & $0.378 *$ & 0.086 \\
\hline & & Sig. level & 0.207 & 0.709 & 0.189 & 0.344 & 0.535 & 0.003 & 0.519 \\
\hline & \multirow[t]{2}{*}{$\mathbf{K}$} & $\mathrm{Sr}$ & 0.075 & -0.064 & $0.316^{*}$ & 0.129 & -0.042 & 0.095 & 0.007 \\
\hline & & Sig. level & 0.578 & 0.634 & 0.016 & 0.336 & 0.753 & 0.478 & 0.956 \\
\hline & \multirow[t]{2}{*}{$\mathbf{L}$} & $\mathrm{Sr}$ & -0.144 & -0.153 & -0.090 & 0.070 & -0.112 & -0.062 & -0.096 \\
\hline & & Sig. level & 0.281 & 0.251 & 0.504 & 0.602 & 0.401 & 0.645 & 0.475 \\
\hline \multirow{6}{*}{ 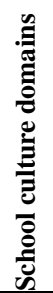 } & \multirow[t]{2}{*}{$\mathbf{M}$} & $\mathrm{Sr}$ & $0.351 *$ & 0.106 & 0.149 & 0.132 & 0.068 & $0.392 *$ & 0.103 \\
\hline & & Sig. level & 0.007 & 0.427 & 0.263 & 0.322 & 0.612 & 0.002 & 0.440 \\
\hline & \multirow[t]{2}{*}{$\mathbf{N}$} & $\mathrm{Sr}$ & $0.499 *$ & $0.290 *$ & $0.477 *$ & 0.161 & 0.157 & $0.669 *$ & 0.251 \\
\hline & & Sig. level & 0.000 & 0.027 & 0.000 & 0.227 & 0.240 & 0.000 & 0.057 \\
\hline & \multirow[t]{2}{*}{$\mathbf{O}$} & $\mathrm{Sr}$ & 0.055 & 0.100 & $0.292 *$ & 0.222 & -0.026 & $0.353^{*}$ & 0.100 \\
\hline & & Sig. level & 0.681 & 0.455 & 0.026 & 0.094 & 0.848 & 0.007 & 0.454 \\
\hline
\end{tabular}

Legend

Same as in Table 4

Based on the results in Table 5, in general, there was a slight relationship between instructional leadership and school culture, even for the high-performing schools. Except for a few, most of the domains were not correlated with each other. For examples, there were significant but weak correlations between:

- Instructional leadership that establishes clear instructional goals with school culture domains that encourage shared vision, teachers as learners, and school-wide planning.

- Instructional leadership that creates a school culture and climate conducive to learning with school culture domains of promoting professional values, mutual empowerment, and transformational leadership.

- Instructional leadership that develops teacher leaders with school culture domains that promote collegiality, shared vision, school-wide planning, and transformational leadership.

\section{Discussion Of Findings}

It is common knowledge that high-performing schools are significantly better than the low-performing schools in many aspects. This is no surprise, including the aspects of school culture and instructional leadership. What is problematic is how to make or induce the low-performing schools to be on par with the high-performing schools. There is no clear-cut solution to this problem, even by the carrot-and-stick theory, path-goal theory, transformational leadership theory, or organizational development theory. No pretensions to be made.

However, the most obvious pattern worldwide is high-performing schools will remain to be high, and the low-performing schools will remain to be low-only in rare cases they can turn around to be highperformers. Probably, the most relevant theory that could explain well this phenomenon is social reproduction theory: the high class and culture will hold their fortress, while the low class and culture will hold their shanty huts. For example, in Malaysia, history and ethos play a major role in determining whether a school is high-performing or low-performing. The residential schools, science schools, junior colleges, mission schools, and elite boarding schools have a long history and tradition of being the best schools, due to the fact that they are highly selective in admitting students, have better facilities, have experienced and better teachers, and strong alumni support. Those schools usually have been the highperforming schools, especially in terms of students' academic achievement. On the other hand, schools located in rural and remote areas are usually the low-performers, commonly suffering from lack of funds and facilities and attended by children 
from the low-income families. The low-performing schools are in disadvantaged or deprived areas.

Another important finding of this study was that, by aggregating the data for both school-types, there were low to moderate significant relationships among many domains of instructional leadership and school culture. However, if the data for the two school-types were separated, then only a few domains were related to each other. This suggests that a bigger sample would yield the former tendency. Further studies are needed to confirm this issue. Whatever it is, scholars need to be cautious when making arguments about the close relationship between instructional leadership and school culture, or viceversa, because the two school-types yield different tendencies. Scholars also need to be wary of the imperfection in definition, conceptualization, and measurement of the two constructs, which need to be either exhaustive or refined further.

Furthermore, an in-depth analysis found that the high- and low-performing schools were culturally similar in two aspects, namely teacher collegiality and shared visions. Collegiality reflects the spirit of togetherness, unity, fraternity, and camaraderie. Teachers, whether in high- or low-performing schools, have this spirit, and together they support the vision of instituting a reputable school, profession, and performance. This study also found that three important traits of instructional leadership related to the culture of high-performing schools were establishing clear vision and goals, creating a facilitative environment and climate for teaching and learning, and developing teacher leaders.

\section{Conclusion}

In any territory, community, or organization, there is a culture and a leader. Leaders and leadership arise in a culture, and they oftentimes reshape culture with their idealism, vision of the future, values, and beliefs. In the reshaped culture, new leaders and leadership arise, and thus the cycle repeats itself. Hence, both culture and leadership are not static in nature; both continuously being changed and reshaped along the time and space dimensions.

The scenario is applicable to school organizations, which have their own unique culture and leadership style. No two schools have the same culture and leadership style. However, there should be some remarkable patterns and characteristics that differentiate the high-performing schools from the low-performing schools. The study presented in this paper was just one of the many attempts in understanding better the remarkable patterns and characteristics that differentiate the two school-types so that the low-performing schools could role-model after the high-performing schools. Similar studies should be done in many other countries, and then a metaanalysis could be made concerning the salient features and concepts surrounding school performance.

\section{References}

[1] G.H. Hofstede \&G.J. Hofstede, Cultures and organizations : Software of the mind(New York: McGraw-Hill, 2005).

[2] E.H. Schein, Organizational culture and leadership (San Francisco: Jossey-Bass, 2004, $3^{\text {rd }}$ ed.).

[3] H. Sufean,Pendidikan di Malaysia: Sejarah, sistem \& falsafah. (Education in Malaysia: History, system \& philosophy)(Kuala Lumpur: Dewan Bahasa \& Pustaka, 2002).

H. Sufean, Memacu puncak ilmu: Autonomi universiti merencana pembangunan (Harnessing the Ivory Tower: University Autonomy in Planning Development) (Kuala Lumpur: Tinta Publisher, 2009).

[4] E. McEwan, Seven steps to effective instructional leadership (California: Corwin Press, 2002).

[5] J. Saphier \& M. King, Good seeds grow in strong cultures. Educational Leadership, 42(6), 1985, 67-74.

[6] P. Hallinger \& K. Leithwood, Unseen forces: The impact of social culture on school leadership. Peabody Journal of Education, 73(2), 1998, 126-151.

[7] R.F. Cavanagh \& G.B. Dellar, The development of an instrument for investigating school culture. Paper presented at the Annual Meeting of the American Educational Research Association, 1996.

[8] Y.C. Cheng, Cultural factors in educational effectiveness: A framework for comparative research. School Leadership \& Management, 20(2), 2000, 207-225.

[9] T.E. Deal \&K.D. Peterson, K. D. (1999).Shaping school culture: The heart of leadership (San Francisco: Jossey-Bass, 1999)

[10] W. Bennis \&B. Nanus, Leaders: The strategies for taking charge (New York: Simon \& Schuster, 1985).

[11] T.J. Sergiovanni, The life world of leadership: creating culture, community, and personal meaning in our schools (San Francisco: Jossey-Bass Publishers, 2000).

[12] C. Mitchell \&J.B. Castle, The instructional role of elementary school principals. Canadian Journal of Education, 28(3), 2005, 409433.

[13] P. Hallinger, Leading education change: Reflections on the practice of instructional and transformational leadership. Cambridge Journal of Education.33(3), 2003, 329-351.

[14] J. Blasé\& J. Blasé, Implementation of shared governance for instructional improvement: Principals' perspective, Journal of Educational Administration, 37(5), 1999, 476-500.

[15] H. Brewer, Ten steps to success. Journal of Staff Development, 22(1),2001, 30-31.

[16] W.K. Hoy\& C. Miskel, Educational adminstration: Theory, research, and practice (Boston: McGraw Hill, 2008). 